\title{
THE PROFESSIONAL LANGUAGE COMPETENCE OF FOREIGN STUDENTS OF MEDICAL SPECIALTIES: CONTENT, FORMS, METHODS OF FORMATION AT HIGHER EDUCATIONAL ESTABLISHMENTS
}

\section{Levenok I. S., Semenog O. M.}

\section{INTRODUCTION}

The dynamic development of medical technologies, globalization and Eurointegration processes in society, recognition of the problem by the world community, the emergence of serious diseases, preserving and promoting health of the population as a national priority of each country determine the special requirements for the professional activity of infectious disease physicians, immunologists, pulmonologists, therapists, pediatricians and other healthcare workers. They should successfully possess fundamental and specific knowledge and skills, provide medical care which complies with the principle of humanity, national and world occupational standards, and actively carry out preventive health care activities. Ukrainian medical education is required among foreign students. The following specialities are popular among foreigners: 222 Medicine, 221 Dentistry, 228 Pediatrics ${ }^{1}$. In accordance with the statistics of the Ukrainian State Center for International Education of the Ministry of Education and Science of Ukraine (USCIE), in 2018, 75605 foreign students study in Ukraine in total ${ }^{2}$. As of the 2017-2018 academic year, more than 23,000 foreign students are receiving medical education in Ukraine, which is about $40 \%$ of the total number of foreign students studying in Ukraine. Most students come to study from India (19.78\%), Morocco (9.77\%), Nigeria (4.70\%), Turkmenistan $(6.66 \%)$, Turkey $(4.30 \%)$, as well as European countries. A request for medical care that meets national and international professional standards provides special requirements for the educational process and for the formation of a competent medical professional with a high level of professional ethics. For successful learning foreign students should know the

${ }^{1}$ Стратегія розвитку медичної освіти в Україні. Міністерство охорони здоров'я України. URL: https://moz.gov.ua/uploads/1/8475-medical_education_analytics.pdf (дата звернення 20.04.2020).

Ukrainian State Center of International Education. URL: https://studyinukraine.gov.ua/ru/zhizn-v-ukraine/inostrannye-studenty-v-ukraine/ (дата звернення 01.04.2020). 
language of another culture. In the professional training of foreign students of different specialties, priority is given to language training, which is a very important factor not only for their rapid adaptation, intercultural communication and integration into the educational environment, but also for their further professional activity and the formation of professional communicative competence. The most popular Ukrainian higher educational establishments among the foreigners are: Kharkiv National Medical University, V. N. Karazin Kharkiv National University, Odessa National Medical University, O. Bogomolets National Medical University, Zaporizhzhia State Medical University, M. I. Pyrohov Vinnitsa National Medical University, IvanoFrankivsk National Medical University, State higher educational institution I. Horbachevsky Ternopil National Medical university of Ukrainian Ministry of Health, Sumy State University ${ }^{3}$. Pedagogical studies in the sphere of professional education, particularly in the process of the state language Ukraine professional training of foreign medical students, have proven the relevance of contemporary forms, methods and means of education in times of digital, innovative approach to a learning process. Student-oriented approach, active student participation in creating educational reality, restructuring of educational curriculum and new requirements in education, fast response to the changes in an educational informative space, open and transparent learning process require reciprocal interaction from both a teacher and student. It stands to the reason that the Ukrainian language in professional education of foreign medical students becomes a mean for professional practice of foreign students in Ukraine, for language competence formation with the purpose to meet the challenges foreign medical students face with in the fight against major diseases globally (for instance, COVID-19) and to duly apply acquired professional skills and abilities. Such circumstances determines the necessity for the advancement of Ukrainian-language professional competence of foreign medical students, particularly when studying disciplines of professional and practical training, doing activities for upbringing and parental education, traineeships where all of these are determined by the branch standards of higher medical education. This problem has become the subject of analysis of the international and state documents ("European Higher Education in the World", Recommendation 2006/962/EU of the European Parliament and the Council (EU) "On Basic Competences for Lifelong Learning" on December 18, 2006., "Mobilizing the brainpower of Europe: enabling higher education to make its full contribution to the Lisbon Strategy,

3 Рейтинги ВУЗів URL: http://ru.osvita.ua/vnz/rating/42226/ (дата звернення 16.03.2020). 
The concept of language training")",4. Ukraine glibly endorses key European Higher Education priorities of Lisbon Strategy. This strategy is intended to deal with the idea of internationalization in education, mobility and recognition. The Analysis of language and communicative aspects, crosscultural aspects of foreign students' professional training, teaching Ukrainian to an audience of non-native speakers were done by N. Avramenko, Z. Bakum, V. Doroz, Y. Karaulov, O. Palchikova and others. Other issues of multicultural approach and national peculiarities are studied by L. Bidenko, V. Zavgorodnii, V. Lonshakova. Other issues of professional practice and adaptation of foreign students to socio-cultural environment are studied by M. Ivanova, I. Melnichuk, Y. Proskurina, O. Surygin and others. At the same time the analysis of scientic and pedagogical sources shows the lack of fundamental studies which would outline the content, forms, methods of Ukrainian-language professional competence formation of foreign medical students. The aim of this study accounts for elaborating on the content, forms, methods of language professional competence formation of foreign medical students in higher education taking into consideration analysis methods for scientific sources. Methods of study: theoretical analysis of scientific sources, legislative and regulatory acts, pedagogical and methodical documents (educational curricula, programs of educational courses), which provided an opportunity to elaborate on theoretical fundamentals of Ukrainian-language professional competence formation of foreign medical students, to determine the status of the issue and its development; empirical - diagnostic methods (questionnaires, observation of the subjects in the learning process); analysis of educational outcomes of students in an educational programme 222 "Medicine" pedagogical experiment aimed at checking the effectiveness of forms and methods of Ukrainian-language professional competence formation.

\section{Ukrainian-language professional competence of foreign medical students in higher education as a scientific and pedagogical issue}

It's necessary to define the basic notions of the study. The notion of "a foreign student" or "an international students" - "students who decided to fully and partly obtain higher education that is different form theirs, and move to another country with the purpose of studying"5. In order to characterize language professional competence of foreign medical students it is necessary to detalize the notion "Language for Specific Purpose" (LSP).

4 European Higher Education in the World. URL: https://www.rlcu.org.ar/ recursos/E_0000032_003_EUROPEANHIGHEREDUCATION.pdf

${ }^{5}$ В доповідях Організації економічного співробітництва і розвитку (OECD - The Organisation for Economic Cooperation and Development) Education at a Glance 2012: Highlights-OECD. URL: http://www.oecd.org/edu/highlights.pdf. 
The notion of "language for specific purposes" (LSP) is used in the pedagogical studies in correlation with the main activity of individual within the framework of using the language as a foreign language for the achievement of professional goals. In this context we detalize the notion "second language personality" is determined by researchers as a set of human abilities to intercultural communication at the intercultural level, interaction with representatives of other cultures. The notion of "a secondary language personality"means knowing not only single lexical units by a foreign student, separate pieces of the mosaic of a foreign language and culture, but a real, conscious professional fluency within intercultural communication. This means the possession of a foreign student not only by individual lexical units, torn pieces of mosaic from another's language and culture, but real, conscious, professional possession within the framework of intercultural communication ${ }^{6}$. The teaching of English for medical and health professions (TEMHP) is a growing enterprise worldwide linked to the rise of English as an international language of health care, global employment flows, and an increasing focus on communication in medical education and practice. The experience of English language teaching for international students in the USA is presented by Barbara J. Hoekje, Sara M. Tiptonin a new context of English language teaching: the emerging, worldwide field of English for medical professionals ${ }^{7}$.

In order to satisfy the communicative needs of foreign students in different spheres of communication: professional (to receive competitive training in the chosen specialty), socio-political and socio-cultural (for proper adaptation and full orientation in the new socio-cultural environment, personal cultural development), household (to meet the needs of daily life), as well as productive education to intercultural dialogue ${ }^{8}$ let us turn to educational, normative and legislative documents.

Language training of foreigners is based on the main provisions of the Constitution of Ukraine, the laws of Ukraine "On Education", the National Program "Education: Ukraine of the 21st Century", the European Charter for Regional or Minority Languages, the European Recommendations on

${ }^{6}$ Levenok I.S. Foreign professional language teaching experience of international medical students (on the example of the USA). International scientific and practical conference "Pedagogy in EU countries and Ukraine at the modern stage»: Conference proceedings, December 21-22, 2018. Baia Mare: Izdevnieciba "BaltijaPublishing», 72-74.

${ }^{7}$ Barbara J. Hoekje, Sara M. Tipton. English Language and the Medical Profession: Instructing and Assessing the Communication Skills of International Physicians. Emerald Group Publishing Limited, 2011. p. 307.

Ушакова Н.І., Дубічинський В.В., Тростинська О.М. Концепція мовної підготовки іноземців у ВНЗ України. URL: http://www-center.univer.kharkov.ua/ vestnik/full/261.pdf. 
Language Education. The study of the Ukrainian language as a separate educational discipline at the I - IV courses of higher medical educational establishments of Ukraine is regulated by Article 48 "Language of Teaching in Higher Educational Institutions" of the Law of Ukraine from 01.07.2014 No. 1556-VII “On Higher Education”.

In the 2016/2017 academic year, at the request of the Concept of Language Training of Foreigners, the discipline "Language of Study (Ukrainian as a Foreign Language)" was introduced in higher education institutions, which is a mean of comprehensive life-long development and a guide for future professionals in their professional development. For foreigners, which study in Ukrainian universities in English form (or other language of study), Ukrainian language becomes the language of sociocultural environment and is necessarily taught in order to develop intercultural communication skills. The ability for intercultural communication is understood as a verbal and non-verbal interaction between people from different cultures. Sometimes the notion of "intercultural communication" is used to describe when one person is trying to interact in a foreign environment, but more often the term is used in the context of communicating with people from two or more cultures trying to understand each other. One of the tasks of language education is to create conditions for foreign students to gain experience in intercultural communication ${ }^{9}$.

Accounting terminological analysis, own practical experience, gives us reason to understand the nature of the notion "Ukrainian-language competence". The ability of a future professional to "navigate in different situations of Ukrainian interpersonal and professional communication which is based on fundamental knowledge, developed communicative skills and abilities that provide for problem solving and meeting specific occupational standards; readiness for professional and communicative activity with a sufficient level of knowledge and competences that had been formed: language, linguistic, pragmatic, coherence, discourse, socio-cultural; the ability to make a Ukrainian-language interpersonal exposure possible in different communicative situations whilst getting over the language barriers, which enables communication practice motivated by the communicative aim; the ability to effectively communicate and take part in professional activity, manage the communication process in Ukrainian at all stages in a professional manner. The analysis of the European Recommendations on Language Education, research works of teachers, psychologists, linguistic

9 Semenog, O., Levenok, I. Intercultural Approach to Forming the Linguistic Competence of Foreign Medical Students: World and Ukrainian Contexts. Spoteczność międzynarodowa $w$ obliczu przemian: ujęcie wieloaspektowe / A. Kordonska, R. Kordonski, (red.); Lwowski Uniwersytet Narodowy im. Iwana Franki, Lwów-Olsztyn, 2019. Tom 1. S. 287-307. 
researchers and others give grounds to determine the meaningful content of the "foreign-language professional competence of foreign students of medical specialties" as a set of interrelated and interdetermined components: language (linguistic), speech, socio-cultural, Ukrainian-language professional competencies.

Experimental work allows to determine the components of Ukrainianlanguage professional competence of foreign students. The components of Ukrainian professional competence of foreign medical students are: the valuemotivational component provides the ability to intercultural interaction, involves the formation of motives and needs, the desire for the development of professional Ukrainian-language competence, the organization of dialogue interaction, communication with a partner on a humanistic basis; the formation of personal qualities (empathy, professional responsibility, language tolerance); the cognitive component covers the formation of knowledge of language norms (lexical (terminological), grammatical, phonetic, orthoepic), the ability to possess medical terminology, norms of highly-specialized text analysis, the culture of reading, speaking and writing); the practical-efficient component includes the professional speech activity and communication, professional linguistic-speaking skills.

This is a debating point. Systematization and generalization of scientific sources, experience of foreign and Ukrainian institutions, made it possible to comprehend the versatility and debating of the problem of formation of Ukrainian-speaking professional competence of foreign students of medical specialties of higher education institutions, and to definitize the Ukrainianlanguage professional competence of foreign students as the future doctors that ensures effective performance of professional duties.

The main aim of speech training at medical faculties is to systematize acquired at home knowledge by a foreign student, which he received from a school program; to deepen knowledge that will be required during the study at the Medical Higher Esducation Establishments (MHEE), mastering the professional terminology of the chosen specialty through mastering the lexical material and speech constructions inherent in the scientific style of speech; to be fluent in language (in reading, translating, listening, summarizing, etc.).

\section{The theoretical backgrounds of formation of Ukrainian-language professional competence of foreign students of medical specialties of higher education institutions}

The theoretical background of the formation of linguistic competence of foreign medical students is the study of foreign experience. In particular, the experience of teaching language to foreign medical students in the United States is presented by scientists from Yale University School of Medicine, Johns 
Hopkins University School of Medicine. Language teaching is conducted "an in-depth, systematic exploration of the professional experiences of non-US born IMGs physicians in primary care practice in the US. Participants reported nuanced, isolating and difficult interactions within workplace hierarchies, and both positive and negative relationships with patients and colleagues. They described "the deal" between IMGs and the US healthcare system, in which IMGs derive certain benefits from practicing medicine in the US, though their professional opportunities are constrained in multiple ways. Finally, they encountered procedural, cultural and systems-related obstacles during the period of transition and throughout their careers" ${ }^{\prime 10}$.

Let us turn to the experience of Germany. Heidelberg University named after Ruprechtand Karl (Heidelberg University) is one of the oldest in Germany and one of the most powerful research universities in Europe. A special feature of the institution is that the Heidelberg School of Medicine, together with the University Clinic, is also a hospital that provides basic and first-class care to patients in the region. There, foreign students apply their knowledge in practice, are medical assistants. The main fields of study of this university are: Heidelberg Medical Faculty, Mannheim Medical Faculty, Central Mannheim Institute for Mental Health, Mannheim Institute for Public Health, Social and Preventive Medicine ${ }^{11}$.

As the analysis of scientific and practical achievements in higher medical education shows, it is important to take into account the general level of students' culture, national peculiarities of education, historical traditions, outlook, ideas about the future profession.

When teaching Ukrainian to foreign students we should take into account their national pequliarities. As the own teaching experience and the teaching experience of teachers of Sumy State University Medical Institute, each representative of the nation has its own language characteristics. For example, Islamic traditions had a great influence on the formation of the character of Arabian students. Such students are respectful of seniors, and consider the profession of doctor as a prestigious one. It is important for the teacher with the Arab students to accept the principle of so-called moderation, which avoids the discussion of acute topics. The peculiarity of students from African countries is slow, but effective learning. They require from the teacher to explain the topic of the lesson, interested in a grounded teaching of the subject. The comparison with the native language is a characteristic feature in studying language for African students. Students

${ }^{10}$ Barbara J. Hoekje, Sara M. Tipton English Language and the Medical Profession: Instructing and Assessing the Communication Skills of International Physicians. Emerald Group Publishing Limited, 2011. p. 307

${ }^{1}$ Welcome to Heidelberg University URL: https://www.uni-heidelberg.de/en. 
from India honor the profession of doctor, because according to their beliefs, the doctor has a great future for the rest of his life. The experience of teaching Ukrainian to Indian students gives us reason to believe that Indian students are responsible, respect the teacher and fulfill their requirements, but do not show activity and not initiative in the learning process ${ }^{12}$.

Let us turn to the national documents under which the language training of foreign medical students is conducted.. As the analysis of the draft State Standard on the Ukrainian language as a foreign language, which regulates the development of unified state requirements for the level set of the Ukrainian language, there is a clear list of communication skills at each level. At A1 level the foreign student understands international words and words from A1 thematic catalog, single inscriptions, simple short texts, etc. At A2 level - the foreign student is able to define the main topic and communicative purpose of the text (general understanding). At B1 level, a foreign student understands the main content of a clear normative statement on known topics within the everyday and professional spheres; understands the main content of the non-adopted text, descriptive and narrative type, general content, its theme and communicative purpose, as well as the details of the text ${ }^{13}$.

It should be noted, that according to the Typical Standard Program of Normative Educational Discipline for foreign students of higher education institutions of the Ministry of Health of Ukraine (Knowledge area: 22 "Health care"), according to the Typical program of the discipline "Ukrainian as a Foreign Language" (English language form of study) for foreign students of Ukraine ${ }^{14}$. As a result of the study, foreign medical students are required to speak Ukrainian at the B1-B2 levels. Level B1 is middle level (professionally oriented). At this level, the formation of communicative competence of a foreign student through the formation of skills in the main types of speech activity (listening, reading, speaking, writing), as well as "mastering vocabulary-oriented vocabulary, involves fixing vocationally colored and was formed in the previous stages, expanding the necessary vocabulary through the professional orientation of

\footnotetext{
12 Левенок І. Соціокультурний аспект становлення вторинної мовної особистості іноземного студента-медика. Рідне слово в етнокультурному вимірі. 2017. C. 413-423. URL: http://nbuv.gov.ua/UJRN/rsev_2017_2017_41.

13 Левенок I. Професійно орієнтований текст як засіб формування мовнокомунікативних навичок іноземних студентів медичних спеціальностей. Педагогічні науки: теорія, історія, інновачійні технології. 4, 2018. С. 112-123. DOI 10.24139/2312-5993/2018.04/112-123.

14 Типова програма 3 дисципліни «Українська мова як іноземна» (англійськомовна форма навчання) для іноземних студентів вищих навчальних закладів MO3 України. URL: http://www.ifnmu.edu.ua/uk/strukturni-pidrozdili2/ kafedry/kafedra-movoznavstva.
} 
the Ukrainian language as a foreign language in accordance with the basic medical disciplines; formation of Ukrainian-language communicative competence of the future specialist being able to solve communicative tasks in the field of professional activity, participate in the dialog communication; demonstration of the sufficient knowledge level of medical terminology because of the foreign students' professional practice in the medical establishments of Ukraine, as well as encouragement of foreign students to the next level of mastering the language $-\mathrm{B} 2$. The $2^{\text {nd }}$ intermediate B2 level (profession-oriented) involves the production of clear smooth logical speech, as well as the adequate efficient and controlled usage of the grammatical structures, connectors and communication circuits ${ }^{15}$.

In order to analyze the process of formation of the Ukrainian-language professional competence of foreign students of medical specialties of Sumy State University, we conducted a survey. Analysis of foreign medical student surveys often shows a low level of motivation to master Ukrainian: this is explained by the fact that the student does not take into account the knowledge of the Ukrainian language when they are at home, and may only be proficient in senior students during their practice in medical instiutions Particular requirements apply to the organization of teachers' dialogue pedagogical interaction with the foreign students. In particular, it is about the ability of teachers to convey to students difficult educational material, taking into account their mentality; about impartiality and respect in pedagogical communication. Important knowledge of the peculiarities of the educational systems of the countries from which they came to study in Ukraine, knowledge of bilingual non-verbal and kinestatic means of communication, etc., understanding of the specifics of a particular religion of students. It is turned out, that new forms, methods of teaching are required.

Having analyzed the work programs of the discipline "Language of study (the Ukrainian language as a foreign)", subject specialization of the specialty 222 "Medicine" in the experimental establishments (Medical Institute of Sumy State University, Ivano-Frankivsk National Medical University, etc.) we may conclude that the discipline "The Ukrainian language as a foreign" is in a coherent connection with the humanitarian subjects more than medical ones, there is the $1^{\text {st }}$ intermediate (professionoriented) level in its structure which involves the lexical and grammatical material mastering with marked profession-oriented direction (Module 4. Module 5. Module 6. Module 7.). Its isolation is motivated by the need to

15 Типова програма 3 дисципліни «Українська мова як іноземна» (англійськомовна форма навчання) для іноземних студентів вищих навчальних закладів MO3 України. URL: http://www.ifnmu.edu.ua/uk/strukturni-pidrozdili2/ kafedry/kafedra-movoznavstva. 
improve the active socio-cultural discourse and consolidation of the profession-colored "speech awareness" that was created and developed in the previous stages; expansion of the necessary vocabulary by the professional orientation of the Ukrainian language as foreign according to the basic disciplines of medical, dental and pharmaceutical profile (human anatomy, physiology, immunology, hygiene and ecology, propedeutics of internal medicine (pediatrics), general surgery, radiology, medical psychology, for the specialties 222 "Medicine" ("General Medicine"), 222 "Medicine" ("Pediatrics"), 221 "Dentistry"); having the professional practice in the relevant medical establishments of Ukraine (nursing practice, industrial medical practice). The main tasks of the $1^{\text {st }}$ intermediate (profession-oriented) level (modules 4-7) are to educate the foreign speakers to have the cognitive interest and respect the Ukrainian language as a tool for the practical usage of acquired professional knowledge; consolidation and improvement of previously formed linguistic, sociolinguistic and pragmatic competences; aiming at mastering the next level of independent user (B2), which involves producing clear smooth logical speech, as well as adequate efficient and controlled usage of grammatical structures, connectors and communication circuits. We work, in particular, on a culture of professional texts reading that promotes the formation of foreign medical students' skills of oral and written speech. The texts, we offer to foreign medical students at B1 level, have the appropriate requirements: authentic or minimally adapted descriptive and narrative texts with elements of reflection related to the professional and educational spheres of life. The usage of profession-oriented texts in classes of Ukrainian language as foreign at Sumy State University is described in details in the previous publications ${ }^{16}$. As our practical experience and experimental work show, the modern manuals, up-to-date books are required.

In 2020, according to the decision of the Department of Linguistics, Ivano-Frankivsk National Medical University, a national (interdepartmental) textbook on the discipline "Ukrainian as a foreign language for Englishspeaking medical students" was printed (Book 1, Book 2). Основнимиструктурнимиодиницями кожного розділу $є$ тематичні блоки (підрозділи). In addition to this book, an audio recording to the listening tasks on the disc is added. There are tasks of different complexity. The main types of tasks are lexical, grammatical, pre-texts, after-texts exercises, tests, listening exercises, development of monological and

\footnotetext{
${ }^{16}$ Левенок I. Професійно орієнтований текст як засіб формування мовнокомунікативних навичок іноземних студентів медичних спеціальностей. Педагогічні науки: теорія, історія, інноваџійні технології. 4, 2018. С. 112-123. DOI 10.24139/2312-5993/2018.04/112-123.
} 
dialogical speech and writing. The authors of the national book became the specialists of one-field departments of such higher educational establishments as Bogomolets National Medical University, National Pirogov Memorial Medical University, Vinnytsya, Zaporizhzhia State Medical University, Sumy State University, Bukovinian State Medical University, Ivano-Frankivsk National Medical University.

We use the Foreign experience of a Polish researcher and teacher, author of books "English for medical students and doctors" (Part 1, Part 2) (Donesch-Jezo, Pachonska-Wolowska, 2014, p. 73) ${ }^{17}$, which studies the problems of teaching English to foreign medical students, indicates that vocationally oriented texts motivate foreign students to master the language quicker. It is easier for students to learn the vocabulary constructions, which are used in context by reading the text. The English for Medical Purposes (EMP) course, which is compulsory at the university level in Poland, is designed to use English in the following areas:1) reading scientific works; 2) oral communication with patients and medical staff; 3) written medical communication (writing medical records, sending letters to specialists, keeping medical records); 4) Making presentations at international conferences ${ }^{18}$.

By our teaching staff (E. Yu. Bournos, I. S. Levenok, N. A. PylypenkoFritsak) a manual for foreign students "Preparing for Clinical Practice" (2018) was prepared. It contains pre-text vocabulary, professional texts, after the text assignments, and "The Test Assignments to the manual "Preparing for clinical practice for foreign students (English form of study) of Medical institute of Sumy State University"'. The main aim of these teaching materials is to create conditions for the formation of linguistic personality, which, as an experience shows, makes easier the process of study theoretical material and practical tasks.

The conducted pedagogical observation, questioning, testing, investigation of the results of student's educational works, practical, educational activity of students, analysis of teachers' lessons in linguistic, special disciplines confirmed the assumption that the process of forming Ukrainian professional competence of foreign students of medical specialties of higher education will be more effective, if the forms and methods of the educational process are developed and updated.

At the same time, the analysis of educational material, books and manuals shows the necessity for modernization and digitization of education

${ }^{17}$ Donesch-Jezo, E., Pachonska-Wolowska, A. Teaching of Vocabulary to Medical Students in ESP Courses. LangLit An International Peer-Reviewed Open Access Journal. 2014. P. 73. URL:https://www.researchgate.net/publication/308914955_Teaching_ of_Vocabulary_to_Medica 1_Students_in_ESP_Courses

18 Ibid. 
with the use of up to date approaches (communicative, cognitive, studentcentered, and other approaches). The pedagogical approaches are overviewed in details in previous publications ${ }^{19}$.

\section{The methodical backgrounds of formation of the Ukrainian-language professional competence of foreign medical students}

In this section, we pay attention to our research and experimental work, which was held at Medical Institute of Sumy State University, IvanoFrankivsk National Medical University, V.N. Karazin Kharkiv National University. The aim was to make approbation of materials and investigate the process of formation Ukrainian-language competence of foreign students medical specialties (during the period from 2016-2020 years).

The research involved foreign students of medical specialties 222 Medicine (English-language form of study). The participants in our study are represented by the following countries: India, African countries, Arab countries. The experimental and control groups were selected in view of the fact that the study in these groups takes place under the same educational conditions and the foreign students are in the same educational and linguistic and cultural environment.

At the motivational (propedeutic) stage (the 1-st year of study), students were directed to the formation of positive motivation for knowledge acquirement, moral convictions, values of the profession, which was carried out in the cultural and educational environment of the Higher Educational medical institution.

According to the questionnaires, students required motivation to learn the language in connection with the bilingual and multicultural socio-cultural environment. This approach was implemented in the course of teaching subjects "Language of study (Ukrainian as a foreign language)", "Fundamentals of academic writing", at practical lessons (setting of problem questions; engaging in discussion; performing test tasks, situational tasks of moral and ethical content), individual work (working with dictionaries), during conferences ("Ethnic consciousness and interethnic interaction in the modern world", "Scientific community of XXI century students", "Cultural personality of the specialist of the 21st century"), thematic events ("The Day of Science", "The Day of Europe", etc.), study excursion-tours, preparation to events ("The student initiation ceremony", "Peace without War", "Mr. Foreign Student"), Participation in project-competitions for foreign

19 Левенок I. Педагогічні підходи до українськомовного навчання іноземних студентів-медиків (на прикладі медичного інституту Сумського державного університету). Педагогічні науки: теорія, історія, інноваційні технології, 8, 2016. 158-167. 
students of the Ministry of Education and Science of Ukraine and the Ukrainian State Center for International Education.

The modern learning process does not go without the classical forms, but blended learning and distance learning also become popular. Let us discuss in more details on distance learning. Distance learning, extract form the legislative document of the Ministry of Education and Science "On approval of the Regulation on distance learning № 466 dated on April 25, 2013" the distance learning is described as "an individualized process of acquiring knowledge, skills, ways and methods of cognitive activity of a person, which occurs mainly through indirect interaction of remote participants of the educational process in a specialized environment, which operates on the basis of modern psychological and pedagogical and information technologies. The purpose of distance learning is to provide educational services through the application of modern information and communication technologies in training at certain educational or educational and qualification levels in accordance with state education standards; to provide programs to prepare citizens for entry into educational institutions, train foreigners and improve the skills of workers. The objective of distance learning is to provide citizens with the opportunity to exercise their constitutional right to education and vocational training, professional development regardless of gender, race, nationality, social and property status, type and nature of occupations, ideological beliefs, belonging to parties, attitudes to religion, religious confession, state of health, place of residence according to their abilities" ${ }^{20}$. We agree with the researcher O. Korbut that "Different methods of providing educational information can be used in distance learning. Several generations of used technologies have already changed - from traditional print editions to state-of-the-art computer technologies (radio, television, audio / video broadcasts, audio / video conferences, E-Learn / online Learn, Internet conferences, Internet

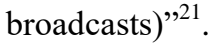

Therefore, for the education and self-study for foreign students, teachers of the department of language training of foreign citizens of Sumy State University prepared at the online platform "Examinarium" (URL: https://examenarium.sumdu.edu.ua/) the distance course "Ukrainian" for English-speaking foreign students. It includes 8 modules (30 lessons). Each lesson contains phonetic and grammar material, test and practical tasks,

${ }^{20}$ Наказ МОН «Про затвердження положення про дистанційне навчання № 466 від 25.04.2013 p. URL: https://zakon.rada.gov.ua/laws/show/z0703-13.

Корбут О.Г. Дистанційне навчання: моделі, технології, перспективи. Матеріали науково-практичної конферениії «Новітні освітні технологї̈». 2013 http://confesp.fl.kpi.ua/en/node/1123 
vocabulary. The audio lessons are included in the lesson, so students can hear sounds, words, dialogues, and text in Ukrainian.

Each lesson is supplemented with self-study tasks, as well as open-ended practical tasks, simulators and tests. The peculiarity of this course is the "feedback" with the teacher, that is, the foreigner record the answers and sends the audio file to the teacher. The teacher, in turn, listens to the pronunciation of sounds, words, sentences of the foreign student and, if necessary, makes adjustments or wishes regarding the student's pronunciation. Such work allows to form linguistic, linguistic competence, and also creates conditions for foreign students to gain experience of intercultural communication, communication in the mode of teacher-student, student-teacher.

At the content-operational stage (the basic stage) (2-3 courses) special attention was paid to ensuring the orientation of the content of educational, practical, professional, social activities, as well as in educational (preclinical) practice students under the guidance of the mentor learned how to make moral conclusions, discussed moral acts in professional activity, mastered the basics of the art of communication with patients of all ages.

Interactive methods were used at all stages of formation language competence. The notion "teaching method" is defined as "an interconnected activity of the teacher and students, which aims students to acquire system of knowledge, acquisition skills and capabilities, their upbringing and general development"22.

Thus, the methods of storytelling, conversation, illustration and demonstration, written work, independent work and repetition are defined. Most of the traditional teaching methods are quite effective, but in the context of modern realities, the optimization of the classical teaching methods is required.

As at this stage, so at further stages, its effectiveness of case-method technology was proved. It is described by researcher O. Medkova as a situational technique, which may help in teaching a foreign language and achieving educational, pedagogic and organizational goals. The usage of this interactive method of learning, allows realize almost all practical knowledge, as well as the ability to predict different situations, to carry on a conversation, to one's opinions, to persuade, to accept criticism adequately, to analyze and make conclusions. The value of this method is in the transformation theory into practice. Discussion of topics, dramatization of created situations, similar to those arising in professional activity and in everyday life, almost theatrical distribution of roles in playing "cases" can method.

${ }^{22}$ Cambridge Dictionary. URL: https://dictionary.cambridge.org/dictionary/english/ 
create not only a creative atmosphere in the classroom, but also solve the main purpose of learning a foreign language.

The foreign scholars, such as Susan F. McLean, point out that the most effective teaching method for medical students is the Case-Based Learning technique. In her research, Susan F. McLean analyzes the experience of using this method in HMIs in Africa, Turkey, India, and America. The authors of the article on dentist education, who took their roots in Turkey, state: "The benefits of the case-based method are to promote self-study, clinical reasoning, clinical problem solving and decision-making, by providing students with repetitive classroom experience and pointing students attention to the complexity of clinical care"23.

The reflexive-evaluation (practical-efficient) stage (4 course) is aimed at ensuring the effective organization of ethical-pedagogical interaction "student - student", "student - teacher", "student - practical medical worker", "student - patient" during educational activity, undergraduate practice, the priority of the development of the individual, humane, civic, moral and ethical characteristics. The modern learning process is not filled with the classical forms of study. The notion "Forms" of study is the Latin world "forma" means outline, appearance, structure of anything. In terms of study, the term "form" is used in two meanings: the form of study and the form of organization of training" ${ }^{24}$. The form of teaching as a didactic category means the external side of the educational process organization. It depends on the goals, content, methods and means of learning, material conditions, the membership of participants in the educational process and its other elements. There are different forms of study, which are defined by the number of students, the time and place of study, the order of its implementation. There are individual, group, frontal, collective, paired, classroom and non-classroom, classroom and out-of-class forms or even virtual forms of education.

Working with a virtual patient is becoming increasingly popular in foreign medical education institutions. For example, the Texas Virtual Laboratory Research Team in Dallas won a grant from National Science Foundation (NSF) to develop and study how augmented reality can help medical students prepare to engage with real patients. As part of its work, the research team develops a natural language interface capable of responding to realistic communication. The team also collects body language data, facials and other physiological information. "Augmented reality means

23 Susan F. McLean. Case-Based Learning and its Application in Medical and Health-Care Fields: A Review of Worldwide Literature. Journal of Medical Education and Curricular Development, 2016. URL: https://journals.sagepub.com/doi/full/ 10.4137/JMECD.S20377.

${ }^{24}$ Словник украӥнської мови: в 11 томах. Том 10, 1979. С. 617. 
that you take reality and add something to it", said Margery Zilke, PhD'07, professor of research and director of the Center for the Modeling and Modeling Laboratory / Virtual People and Synthetic Societies. "In this study, we explore the role that real peers, virtual peers, real professors, and virtual professors play in teaching patient communication" 25 . It is necessary to mention, that Virtual Patient is also used in Ukrainian educational institutions (in particular at Ivano-Frankivsk National Medical University) as an integral part of the training of foreign medical students.

The demands of digital society dictate changes and didactic means. The group researchers O. Semenog, O. Semenikhina, D. Bezuhlyi defined the digital creative environment "as such a learning environment, which involves the purposeful use of tools, technologies and information resources that enable the creative expression of personality by means of digital technologies, integrating information and communication technologies, intellectual systems, human sensitivity and contextual activity"26. The means (or Learning tools) are a source of knowledge acquisition, skills formation. These include visual aids, textbooks, didactic materials, technical aids, study quest-rooms, labs, and other media (computer visualization. Mental maps). In the process of formation of Ukrainian-language professional competence of foreign medical students we use the following training tools, such as electronic textbooks, virtual laboratories (for example, ULab SSU), blogs, professional-oriented social media pages. While the formation of Ukrainianlanguage professional competence of foreign medical students we use the authorial Ukr.Lang.Laboratory for foreign students (Ukrainian language and professional oriented laboratory for foreign students of SSU) a professionaloriented account on the social network "Ukr.Lang.Laboratory for foreign students" (https://www.facebook.com/groups/2580388622284576/). The information in "Ukr.Lang.Laboratory for foreign students" is provided for foreign students as an initial level of proficiency in Ukrainian A1-A2 (video materials for beginners, podcasts, cards for studying basic lexical material, e-dictionaries), as well as for students-foreigners of advanced courses, for the purpose of professional fluency in the language, taking into account the medical direction, at the level B1-B2 (texts of medical direction, video and audio materials, visual cards). Within "Ukr.Lang.Laboratory for foreign students" the excursion method is used as a set of tools and techniques of

\footnotetext{
${ }^{25}$ Phil Roth. Virtual Patient Project Aims To Develop Smarter Medical Students. URL: https://www.utdallas.edu/news/science-technology/augmented-reality-zielke-nsfgrant-2020/.

26 Семеног О.М. Формування академічної культури майбутніх педагогівдослідників в умовах цифрового творчого середовища як наукова проблема / О.М. Семеног, О.В. Семеніхіна, Д.С. Безуглий. Інформаційні технологї̈ $i$ засоби навчання, 2017. Vol. 62. 6. С. 240-252.
} 
knowledge transfer during the excursion. Foreign students of medical specialties may travel virtually to Netherlands and visit "The Museum of Human's Body". At "Ukr.Lang.Laboratory for foreign students" foreign students of medical specialties may try to create their first projects. So, we see the effectiveness of social networks in language training of foreign students.

\section{CONCLUSIONS}

Taking into account the above-stated (with the use of the theoretical methods of investigation - the analysis of the foreign, national and personal experience; legislative and educational sources; empirical diagnostic method - questionnaires, observation; some results of pedagogical experimental investigation) we may conclude, that the process of formation of the professional language competence of foreign students of medical specialties, as in Ukraine, so abroad, is complex and requires the enhancement and modernization of forms, methods of language study of foreign students medical specialties at higher educational establishments. In the first paragraph "Ukrainian-language professional competence of foreign medical students in higher education as a scientific and pedagogical issue" we defined the basic notions, the content on theoretical fundamentals of Ukrainian-language professional competence formation of foreign medical students, to determine the status of the issue and its development. It was determined the meaningful content of the "foreign-language professional competence of foreign students of medical specialties" as a set of interrelated and interdetermined components: language (linguistic), speech, sociocultural, Ukrainian-language professional competencies. Experimental work allows to determine the components of Ukrainian-language professional competence of foreign students (the value-motivational, cognitive, practicalefficient components). In the second paragraph "The theoretical backgrounds of formation of language professional competence of foreign students of medical specialties of higher education institutions" it is analyzed not only Ukrainian experience, but the experience of the USA, Germany and Poland. The conducted pedagogical observation, questioning, testing, investigation of the results of student's educational works, educational activity of students, analysis of teachers' lessons in linguistic, special disciplines confirmed the assumption that the process of forming Ukrainian professional competence of foreign students of medical specialties of higher education will be more effective, if the forms and methods of the educational process are developed and updated. At the same time, the analysis of educational materials, books and manuals shows the necessity for modernization and digitalization of education. In the third paragraph "The methodical backgrounds of formation of the Ukrainian-language professional competence of foreign medical 
students" the attention is payed at three stages of our experiment. We made an attempt to prove the effectiveness of modern methods, forms and some means in language study of foreign students of medical specialties.

\section{SUMMARY}

In our investigation it was outlined the content, forms, and methods of formation the professional language competence of foreign students of medical specialties at higher educational establishments. The definitive analysis of the basic notions, the content on theoretical fundamentals of Ukrainian-language professional competence formation of foreign medical students was made in order to determine the status of the issue and its development. It was analyzed not only Ukrainian experience, but the experience of the USA, Germany and Poland. It was turned out, that the process of formation of the professional language competence of foreign students of medical specialties, as in Ukraine, so abroad, is complex and requires the enhancement and modernization of forms, methods of language study of foreign students' medical specialties at higher educational establishments. It was determined the components of Ukrainian-language professional competence of foreign students (the value-motivational, cognitive, practical-efficient components). The three stages of our experiment were analyzed. We made an attempt to prove the effectiveness of modern methods, forms and some means in language study of foreign students of medical specialties.

\section{REFERENCES}

1. В доповідях Організації економічного співробітництва і розвитку (OECD - The Organisation for Economic Cooperation and Development) Education at a Glance 2012: Highlights-OECD. URL: http://www.oecd.org/ edu/highlights.pdf.

2. Корбут О.Г. Дистанційне навчання: моделі, технології, перспективи. Матеріали науково-практичної конференції «Новітні освітні технології». 2013 http://confesp.fl.kpi.ua/en/node/1123.

3. Левенок I. Педагогічні підходи до українськомовного навчання іноземних студентів-медиків (на прикладі медичного інституту Сумського державного університету). Педагогічні науки: теорія, історія, інноваиійні технологіï. 8, 2016. 158-167.

4. Левенок I. Соціокультурний аспект становлення вторинної мовної особистості іноземного студента-медика. Рідне слово в етнокультурному вимірі. 2017. C. 413-423. URL: http://nbuv.gov.ua/ UJRN/rsev_2017_2017_41.

5. Левенок I. Професійно орієнтований текст як засіб формування мовнокомунікативних навичок іноземних студентів медичних 
спеціальностей. Педагогічні науки: теорія, історія, інновачійні технології. 4, 2018. C. 112-123. DOI 10.24139/2312-5993/2018.04/112-123.

6. Наказ МОН «Про затвердження положення про дистанційне навчання № 466 від 25.04.2013 p. URL: https://zakon.rada.gov.ua/laws/ show/z0703-13.

7. Рейтинги ВУЗів URL: http://ru.osvita.ua/vnz/rating/42226/ (дата звернення 16.03.2020).

8. Семеног О.М. Формування академічної культури майбутніх педагогів-дослідників в умовах цифрового творчого середовища як наукова проблема / О.М. Семеног, О.В. Семеніхіна, Д.С. Безуглий. Інформаційні технології $і$ засоби навчання. 2017. Vol. 62. 6. С. 240-252.

9. Словник української мови: в 11 томах. Том 10, 1979. С. 617.

10. Стратегія розвитку медичної освіти в Україні. Міністерство охорони здоров'я України. URL: https://moz.gov.ua/uploads/1/8475medical_education_analytics.pdf (дата звернення 20.04.2020).

11. Типова програма 3 дисципліни «Українська мова як іноземна» (англійськомовна форма навчання) для іноземних студентів вищих навчальних закладів MO3 України. URL: http://www.ifnmu.edu.ua/uk/ strukturni-pidrozdili2/kafedry/kafedra-movoznavstva.

12. Ушакова Н.І., Дубічинський В.В., Тростинська О.М. Концепція мовної підготовки іноземців у ВН3 України. URL: http:// www-center.univer.kharkov.ua/vestnik/full/261.pdf.

13. Barbara J. Hoekje, Sara M. Tipton English Language and the Medical Profession: Instructing and Assessing the Communication Skills of International Physicians. Emerald Group Publishing Limited, 2011. p. 307.

14. Cambridge Dictionary. URL: https://dictionary.cambridge.org/ dictionary/english/method.

15. Donesch-Jezo, E., Pachonska-Wolowska, A. Teaching of Vocabulary to Medical Students in ESP Courses. LangLit An International Peer-Reviewed Open Access Journal. 2014. P. 73.

URL:https://www.researchgate.net/publication/308914955_Teaching_ of_Vocabulary_to_Medica 1_Students_in_ESP_Courses.

16. European Higher Education in the World. URL: https://www.rlcu.org.ar/recursos/E_0000032_003_EUROPEANHIGHERED UCATION.pdf.

17. Levenok I.S. Foreign professional language teaching experience of international medical students (on the example of the USA). International scientific and practical conference "Pedagogy in EU countries and Ukraine at the modern stage»: Conference proceedings, December 21-22, 2018. Baia Mare: Izdevnieciba «BaltijaPublishing», 72-74.

18. Semenog, O., Levenok, I. Intercultural Approach to Forming the Linguistic Competence of Foreign Medical Students: World and Ukrainian 
Contexts. Społeczność międzynarodowa $w$ obliczu przemian: ujęcie wieloaspektowe / A. Kordonska, R. Kordonski, (red.); Lwowski Uniwersytet Narodowy im. Iwana Franki, - Lwów-Olsztyn, 2019. Tom 1. S. 287-307.

19. Susan F. McLean. Case-Based Learning and its Application in Medical and Health-Care Fields: A Review of Worldwide Literature. Journal of Medical Education and Curricular Development, 2016. URL: https://journals.sagepub.com/doi/full/10.4137/JMECD.S20377.

20. Ukrainian State Center of International Education. URL: https://studyinukraine.gov.ua/ru/zhizn-v-ukraine/inostrannye-studenty-vukraine/ (дата звернення 01.04.2020).

21. Virtual Patient Project Aims To Develop Smarter Medical Students. URL: https://www.utdallas.edu/news/science-technology/augmented-realityzielke-nsf-grant-2020/.

22. Welcome to Heidelberg University URL: https:// www.uni-heidelberg.de/en.

\section{Information about the authors:}

Levenok I. S.,

Postgraduate Student at the Department of Ukrainian Language and Literature A. S. Makarenko Sumy State Pedagogical University, Lecturer at Language Training for Foreign Students Department Sumy State University 87, Romenska str., Sumy, Ukraine

Semenog O. M., Doctor of Pedagogic Sciences, Professor, Head of the Department of Ukrainian Language and Literature of the Faculty of Foreign and Slavic Philology A. S. Makarenko Sumy State Pedagogical University 87, Romenska str., Sumy, Ukraine 